\title{
The Tanakh as History
}

\author{
Marc Zvi Brettler
}

As a scholar of the Hebrew Bible, one of the most difficult questions that I regularly face is determining the genre of different biblical texts. ${ }^{1}$ Interpretation of any literary text, including the Bible, involves much more than understanding its grammar and lexicon-it must take into consideration genre as well, since the very same words take on different meanings depending on the genre to which they belong. To take a contemporary example: the same words appearing in a newspaper headline and in a comic strip or in a satire may convey or mean something different. ${ }^{2}$

The Bible, like other ancient Near Eastern texts, does not include genre labels that help us understand how particular texts should be "genrified." To stay within the Torah: Are the initial chapters of Genesis to be understood as science or as natural history? Are the ancestral stories meant to be "real" history, narrating the true events of real people in real places at real times - in other words, "history" in its most common contemporary usage? Or do these stories have a different purpose, and are we misreading them if we take them as intending to convey real history, just as we would be misreading a mystery novel set in the past if we read it as history?

This problem is severe and difficult to solve. It is even difficult to know what our presumptions as readers of this material should be, since, after all, the Torah does not open with the words "read me as science (or natural history)," nor does parashat Lekh Lekha (Gen. 12:1 and following) begin by saying, "The following should be read as an account of what actually happened in the $\mathrm{x}$-th century BCE." This last point is not trivial, and suggests that as we approach each text, we must ask: What is its genre? Why was it written? What was it trying to convey?

Unlike most of the contributors to this volume, I am American, and thus I am especially sensitive to how issues concerning the Bible as history resonate in the U.S., in both the Jewish and general community. In the non-Jewish, 
Protestant world, many conservative believers take as a matter of faith the literal truth of the Bible and its inerrancy. An important evangelical document from 1978 includes a declaration of the wholeness of the Bible and its inerrancy. Its fifteenth article states:

WE AFFIRM the necessity of interpreting the Bible according to its literal, or normal, sense. The literal sense is the grammatical-historical sense, that is, the meaning which the writer expressed. Interpretation according to the literal sense will take account of all figures of speech and literary forms found in the text.

WE DENY the legitimacy of any approach to Scripture that attributes to it meaning which the literal sense does not support. ${ }^{3}$

I believe that especially in America, this Protestant view, which was developed late in the nineteenth century and early in the twentieth, has influenced Judaism, and as a result some Jews, trying to show that they are at least as "frum" as their Protestant counterparts, have taken over as doctrine some of these fundamentalist principles. For different reasons, often connected to politics, the history of Israel as recounted in the Bible is often taken at face value among various groups of the contemporary Israeli population as well, just as some anti-Zionist biblical scholars have been quick to overemphasize the problems of using the Bible as a historical source. ${ }^{4}$ Yet a close look at the historical record of Jewish interpretation indicates that material such as the primeval story in Genesis 1-11 and the ancestral narratives in 12-50 have often not been understood as literal_-or as primarily literal—within Jewish tradition. I will address this later, when I explore precedents for this position. I am happy for these precedents - it is important that each generation not recreate the wheel. Yet for me, such precedents are not crucial. It is clear that Judaism, even (!) traditional Judaism, innovates, and thus I do not want to exaggerate the importance of precedents, or to buy into the position that hadash asur min ha-Torah, that we are enjoined by the Torah from innovating. ${ }^{5}$

As I have indicated elsewhere, I do not believe that the ancients understood the writing of history as we now do. ${ }^{6}$ There was little, if any, interest in narrating the past for its own sake. Stories were set in the past for a variety of reasons, but antiquarian interest was not one of them. ${ }^{7}$ Though sparks of such interest developed in the Renaissance, it came to fruition only in the nineteenth century, and it would be a grave mistake to read the biblical books as the products of those German universities with an interest in recreating history 
"wie es eigentlich gewesen," namely, how it really was. Instead, the "historical" traditions of the Bible should be understood broadly within their ancient context, and more narrowly within their ancient Near Eastern context. In that world, what were the purposes of narratives depicting a past?

One of the most clear, provocative, and convincing discussions of this issue is reflected already in the title of ancient historian Paul Veyne's Did the Greeks Believe in Their Myths? An Essay in Constitutive Imagination. ${ }^{9}$ Although his answer to this question is subtle and multifaceted-for after all, there is no single Greek conception just as there is no single Jewish conception-his main contention (and here he is far from alone) is that the ancient classical historians were not primarily interested in presenting the past accurately from a historical perspective, but in producing useful narratives about the past. ${ }^{10}$ Veyne suggests that, in general, the ancients did not understand their myths and their historical accounts (and there is good reason to combine these two types of stories and to treat them together) as true in the same sense as simple declarative sentences such as, "This amphora is made of clay." The ancient Greek myths were understood to be true in a different, nonliteral sense.

Coming closer to the biblical world, the same conception is well attested in the Mesopotamian historiographical tradition. Concerning one Mesopotamian chronicle, the modern Assyriologist Jean-Jacques Glassner notes: "The author was not interested in producing a chronicle of past centuries ... his aim was to make a theology of them.... He wished to propose an explanation of them on the religious level." ${ }^{11} \mathrm{He}$ also notes the use of figurative, metaphorical, and nonliteral use of language in some of these texts. ${ }^{12}$ Several scholars call these texts propaganda, using this term not in its contemporary pejorative sense, but in its more neutral, earlier sense of a text that is attempting to establish and propagate a particular viewpoint. ${ }^{13}$ Others note similarly the ideological cast of these texts, ${ }^{14}$ and their "outright political polemic." ${ }^{15}$ Many of these points can be seen most clearly in texts such as the Weidner Chronicle, which contains many historical fabrications, and uses the past to show that the king must properly honor the Babylonian high god Marduk. ${ }^{16}$ By highlighting such texts in reference to biblical historical texts, I am simply saying that these ancient Jewish texts should be understood in their broader context, taking into consideration that "disinterested research into the past or objective reporting of current events was virtually nonexistent in antiquity." 17

This idea that the past is not important for its own sake is also amply illustrated in rabbinic texts, as noted by Isaiah Gafni, who observes that "the events of the Bible were known to all, and it was their meaning and moral implications 
that would be taken up by the rabbis." ${ }^{18}$ I would go a step further-the rabbis take up "their meaning and moral implications" precisely because that is what these texts were originally about. Gafni notes astutely that the biblical injunction, "You have to inquire about bygone ages that came before you, ever since God created man on earth, from one end of heaven to the other: has anything as grand as this ever happened, or has its like ever been known?" (Deut. 4:32) was not used by the rabbis to encourage study of the past for its own sake. I would add that in this case the rabbis were simply following biblical precedent, according to which the past also was not important for its own sake. Gafni also studies the expression mai de-hava hava, which appears fourteen times in the Babylonian Talmud. He notes that the expression does not suggest that history in the sense of recreating the real past is irrelevant, but that it is a distraction. ${ }^{19}$ I believe that the same is true of biblical texts as well; they were interested in what stories might teach, rather than in the real, actual past.

Had the Bible shown a strong interest in the actual past, it would look very different. It would not state in its first chapter that land animals were created, and then man and woman, and then one chapter later claim that man was created first, then land animals, and then woman. Works that are historical, in the sense of recapitulating the actual past, clean up such basic inconsistences. Nor do books interested in the real past tell the same story twice-as is the case in Samuel-Kings and Chronicles. Not only would a real historian in the modern sense have included only one of these texts, but he or she would have also decided such basic issues as whether David or Elhanan killed Goliath (1 Sam. 17; 2 Sam 21:19), or if Elhanan killed Goliath's brother (1 Chron. 20:5), to say nothing of whether or not David sinned with Bathsheba (2 Sam. 11-12; 1 Chron. 20:1-3). A work interested in "real" history would know the number and order of the plagues in Egypt (Ps. 78; 105), and would have been clear about whether the plague of blood, for example, only affected the Nile or all Egyptian bodies of water (Exod. 7:20-21). The conclusion to my mind is clear: the Bible as a whole-as well as individual biblical compositions that discuss ancient events - is not interested in the real history of the past.

Though I wish I could find a better term, I contend that the biblical stories about the past are best understood as "myth." I am not using "myth" in the sense of a primitive story, a story that is wrong, or a story about the gods, but rather in the more technical sense, as the word is used by anthropologists and others. I find most useful, and am most sympathetic to, a modified version of the definition offered by the classicist Walter Burkert: a myth should be understood as a traditional tale dealing with issues of collective importance, and is an extended 
metaphor. ${ }^{20}$ For him, as for me, "myth" is a descriptive term, with no negative value judgment whatsoever.

As such, I do not accept the frequent scholarly distinction that classifies the introductory stories of Genesis as myth, while considering those beginning with Abraham as history. Both groups of stories are traditional tales dealing with issues of collective importance. The late biblical scholar Matitiahu Tsevat expressed this notion brilliantly in observing that from the biblical perspective "the waters of Noah are no less real than the waters of Shiloah." ${ }^{21}$ In other words, the stories in Genesis are not presented differently than other accounts, suggesting that they belong to the same genre as the stories in Kings (e.g., 2 Kings 20:20), including those that have archeological corroboration. His observation is supported by the structure of Genesis, which does not indicate a clear break between what many scholars consider myth and what they consider to be history; indeed, Abraham is introduced in the genealogy in Genesis 11:26, and that genealogy in its first verse $(11: 10)$ dates the birth of Shem to "two years after the flood." It is also supported by the structure of so-called "historical psalms," such as Psalm 136, which notes both "who made the heavens with wisdom, His steadfast love is eternal" (5) and "who led His people through the wilderness, His steadfast love is eternal" (16). In sum, my inclination is to treat all biblical narratives that depict a past as myths in Burkert's sense. ${ }^{22}$

These traditional tales may, of course, contain "kernels," to use a word fashionable last century, of historical veracity. In some cases they may even be used to reconstruct the real history of Israel, a real people in the Iron Age Levant. But that was not their main purpose. To return to Burkert, as myths they are metaphors on the story level. It is a fundamental mistake of mis-genrification to read them as if they intended to retell the story of ancient Israel in the same way that, for instance, a modern historian of the 1948 War of Independence is judged by how well he or she fulfilled the goal of approaching the real truth of what happened.

As such, I find myself in basic disagreement with Saadya, the first Jewish biblical commentator, who has been unduly influential in the world of Jewish commentary. In his Book of Beliefs and Opinions he notes that a literal sense of the biblical text should be upheld unless it contradicts the senses, reason, another biblical passage, or rabbinic tradition:

Now that I have finished explaining the three types of knowledge [i.e., rational, scriptural, and traditional] which are necessary for the commentator on the Torah, I see fit to preface [a description of] the [proper] 
method of expounding the Torah and the other books of the Prophets. I say: since these three types of knowledge are the very foundations of Scripture, and since every speech includes perforce both unambiguous and ambiguous [expressions; in Arabic, muhkam and mutashabih] ... the exegete should consider all words that accord with the prior dictates of reason and the later dictates of tradition as unambiguous, and words that are inconsistent with one or the other as ambiguous.

To explain further: a reasonable person should always understand the Torah according to the external meaning of its words, that is, the meaning generally recognized among speakers of the language-because the purpose of any book is to convey its meaning perfectly in the reader's heart-except where perception or reason contradict the usual meaning of a particular expression or where the usual meaning of an expression contradicts an unequivocal verse found elsewhere in Scripture or tradition. However, if retaining the simple meaning of an expression leads the exegete to profess one of these four things [discussed below] he must know that this expression is not to be understood according to its simple meaning, but that it carries one or more nonliteral meanings [majaz]; and once he knows the type of majaz involved ... in order to bring [the expression under consideration into agreement with] its unambiguous equivalent $[$ muhkam $]$, the verse will be reconciled with the senses, with reason, with other scriptures and with tradition. ${ }^{23}$

This position, which has its contemporary advocates, ${ }^{24}$ assumes a clear bias toward the literal, and has been extremely influential within Judaism. Yet it is far from determinative, and Maimonides, considered by many to be the greatest of the medieval theologians, did not support his predecessor's view. Maimonides argues quite differently in his introduction to The Guide of the Perplexed that the true and important words of Scripture are like a hidden pearl, and external meanings do not suffice; rather "their internal meaning, on the other hand, contains wisdom that is useful for beliefs concerned with the truth as it is." 25 Throughout the Guide he develops this principle, offering, as is wellknown, many allegorical interpretations of biblical passages; in fact, Mordechai Cohen has claimed that he "made metaphor the exegetical focus of his Guide for the Perplexed." 26

In his exposition about the importance of inner meaning, Maimonides cites Proverbs 25:11: "Like golden apples in silver showpieces is a phrase well turned." The late great medievalist Frank Talmage used this citation as the basis 
for his brilliant essay "Apples of Gold: The Inner Meaning of Sacred Texts in Medieval Jewry." 27 Talmage shows that this idea that biblical texts possess an inner meaning is key in much medieval interpretation. For example, Joseph Kimhi in The Book of the Covenant noted that Jews understand the Bible figuratively in a way that is comparable to eating the marrow of the bone and wheat rather than the chaff. ${ }^{28}$ This is, of course, especially remarkable since that book was written in the context of Jewish-Christian polemics, and Christianity typically understood the Hebrew Bible allegorically. Nevertheless, Kimchi did not draw a clear contrast between Jewish literal and Christian allegorical interpretation, although he did suggest a difference of extent concerning the allegorical interpretation of the Bible. ${ }^{29}$ Talmage sees the Zohar as epitomizing this attitude in its claim:

Rabbi Simeon said: Alas for the man who regards the Torah as a book of mere tales and profane matters. If this were so, we might even today write a Torah dealing in such matters and still more excellent. In regard to earthly things, the kings and princes of the world possess more valuable materials. We could use them as a model for composing a Torah of this kind. But, in reality, the words of the Torah are higher and higher mysteries. When even the angels come down into the world [to fulfill a mission], they don the garments of this world, and if they did not, they could not survive in this world and the world could not endure them. And if this is true even of the angels, how much more true is it of the Torah, with which he created them and all the worlds and through which they all subsist. When she descends into the world, how could the world endure it if she did not don earthly garments? If anyone should suppose that the Torah herself is this garment and nothing else, let him give up the ghost. Such a man will have no share in the world to come. That is why David (Ps. 119:18) said: "Open thou mine eyes, that I may behold wondrous things out of thy Torah,” namely, that which is beneath the garment of the Torah. Come and behold: there are garments that everyone sees, and when fools see a man in a garment that seems beautiful to them, they do not look more closely. But more important than the garment is the body, and more important than the body is the soul. So likewise the Torah has a body, which consists of the commandments and ordinances of the Torah, which are called gufei torah, "bodies of the Torah." This body is cloaked in garments, which consist of worldly stories. Fools see only the garment, which is the narrative part of the Torah; they know no more and fail to see what is under the garment. 
Those who know more see not only the garment but also the body that is under the garment. But the truly wise, the servants of the Supreme King, those who stood at the foot of Mount Sinai, look only upon the soul, which is the true foundation of the entire Torah, and one day indeed it will be given them to behold the innermost soul of the Torah. ${ }^{30}$

Talmage adduces much more evidence from a variety of periods. He observes that the beginning of Genesis was considered esoteric, and thus nonliteral, by the sages in Babylonian Talmud tractate Hagigah $11 \mathrm{~b} .{ }^{31}$ He notes, for example, that Isaac Arama understood Abraham's saddling his ass in Genesis $22: 3$ as a symbol for subduing the material aspects of life, ${ }^{32}$ as well as referring to Bahya ben Asher's ${ }^{33}$ more general pronouncement that "the superiority of the esoteric over the exoteric is as the superiority of gold over silver." ${ }^{34}$ Talmage concludes the essay with an afterword where he observes that from the study of medieval interpretation we might glean the very principle of freedom of interpretation itself, that the scriptures, biblical or postbiblical, bear more than one meaning, that a modernist approach to a text need not rule out a commitment to belief in tradition. Thus, one retains one's foundation without fundamentalism, one's faith in the Creator without creationism. ${ }^{35}$

The position that biblical texts that depict the past should not be read as depicting the actual past is especially pronounced in the interpretive traditions surrounding the book of Job. As is well-known, among the various opinions cited concerning Job in the long Talmudic discussion in Babylonian Talmud tractate Bava Batra 15a-b is the opinion that Job never existed, but was written as a parable. ${ }^{36}$ This position was sometimes reasserted in medieval Jewish interpretation - for example, in the work of the late thirteenth-century scholar Zerahiah of Barcelona. ${ }^{37}$ Maimonides understood Job as a parable, and suggested that readers of the book should "meditate and reflect on this parable, grasp its meaning, and see what the true opinion is [concerning divine retribution]."38

The case of reading Job as a parable is especially important. Job does not open with the words "do not read me literally." Its initial chapter seems to describe real people, real sheep, and even three real friends who travel from real countries, and, who upon seeing Job, perform real mourning rituals. The book begins: "There was a man (ish haya) in the land of Uz named Job. That man was blameless and upright; he feared God and shunned evil. Seven sons and three daughters were born to him; his possessions were seven thousand sheep, three thousand camels, five hundred yoke of oxen and five hundred she-asses, 
and a very large household. That man was wealthier than anyone in the East" (Job 1:1-3).

As Avi Hurvitz has shown, the construction ish haya is the Late Biblical Hebrew equivalent of vayehi ish ehad. ${ }^{39}$ In that sense, the book's opening is nearly identical to that of the book of Samuel: "There was a man (vayehi ish ehad) from Ramathaim of the Zuphites, in the hill country of Ephraim, whose name was Elkanah son of Jeroham son of Elihu son of Tohu son of Zuph, an Ephramite. He had two wives, one named Hannah and the other Peninah; Peninah had children, but Hannah was childless" (1 Sam. 1:1-2).

To my mind, this raises an obvious question: Should we read Samuel as a parable, and not as a literal, factual narration of the beginning of the monarchy in ancient Israel? And what of other stories that seem to begin with the factual words vayehi ish ehad, such as the Samson narrative in Judges 13? And what of similar stories about the past that happen not be begin with those same words? I would answer yes to all of these questions. Given what we know about how and why stories set in the past were written and used in ancient Israel, there should be no bias toward reading these stories as accounts of real historical events. To borrow the image of Joseph Kimhi, that type of reading would involve silver and chaff rather than gold and wheat.

The position that sections of the Bible should not be read literally has found much resonance in Jewish discussions of the beginning of Genesis in the recent century and a half. This resonance is related to the Jewish acceptance of many (though not all) aspects of Darwin's theory of evolution, which certainly contradicts a literal reading of the beginning of Genesis; the Bible nowhere suggests that life on earth evolved from a common, original life-form. To return to my earlier discussion concerning biblical language and myth, this reading involves understanding these biblical texts nonliterally, and suggests that science and religion speak different languages. ${ }^{40}$ Abraham Isaac Kook, the first Ashkenazi chief rabbi of Mandatory Palestine (1865-1935), was especially well-known for his attraction to aspects of evolution, which he believed conformed to certain kabbalistic notions. In a letter to his friend, the traditional biblical scholar Moshe Seidel, he noted: "The Torah obviously obscures the account of creations and speaks in allusions and parables." 11 Yeshayahu Leibowitz, a scientist by training, also believed that the Bible cannot be taken literally, and claimed that "religion is not about facts; it is a decision to worship God." 42

Perhaps the best articulation of this position was in a letter written by the young S. R. Hirsch, considered the founder of Neo-Orthodoxy (1808-1888): "As Jews we will read this book, as a book tendered to us by God in order that 
we learn from it about ourselves, what we are and what we should be during our earthy existence. We will read it as Torah-literally, 'instruction' - directing and guiding us within God's world and among humanity, making our inner self come alive." ${ }^{43} \mathrm{He}$ also noted that "Jewish scholarship has never regarded the Bible as a textbook of physical or even abstract doctrines," and he was thus open to many facets of the theory of evolution. ${ }^{44}$

Throughout history, many Jewish rabbis and scholars accepted scientific theories produced by any scientist, regardless of his or her religious commitment. In medieval times, Judaism appropriated Greek and Arab science ${ }^{45}$; later Rabbi Moshe Isserles (Rama) even wrote a commentary on Georg Peurbach's 1456 New Theory of the Planets. ${ }^{46}$ The medieval Jewish reception of (Christian) scientific theories in the early modern period was varied, but overall open and positive. $^{47}$

The nineteenth-century rabbinic attitude to modern science included positive responses. ${ }^{48}$ Certainly there are significant pockets of resistance, including Chabad and others who insist on the literal interpretation of the beginning of Genesis in conjunction with the claim that science can only develop theories, as opposed to the ultimate truths of the Torah (taken literally). ${ }^{49}$ More recently, Natan Slifkin's positions concerning the commensurability of evolution and the creation stories of Genesis received some support in the Orthodox community, until it was roundly condemned in the Haredi community. ${ }^{50}$ The contemporary American Jewish philosopher Norbert Samuelson has also argued for commensurability by interpreting biblical texts nonliterally as "Holy Narrative," a term that he uses in a manner similar to my use of "myth." ${ }^{11}$ I commend his honesty in noting that "in my judgment this problem of the reliability of the historical sections of the Hebrew scriptures is the single most important challenge raised by modern science to the believability of any form of rabbinic or neo-rabbinic Judaism." 52

The position of Leibowitz and others that science and religion speak different languages should be more generally aligned with a Kantian argument that was more fully developed by the great (Jewish) Harvard University evolutionary biologist Stephen Jay Gould (1941-2002). Gould spoke of science and religion as "non-overlapping magisterial"; this phrase was so important for him that he even abbreviated it as "NOMA." 53 The American analytic philosopher Alvin Plantinga has defended a similar position in Where the Conflict Really Lies: Science, Religion, and Naturalism, ${ }^{54}$ arguing that "there is superficial conflict but deep concord between science and theistic religion." 55 As a neoKantian, it is not surprising that Joseph B. Solovetchik was also sympathetic 
to this position. ${ }^{56}$ Of course, much of this discussion depends on the precise definitions of science and religion, and it is not the case that all of the insights offered by Christian scholars concerning this issue as it relates to Christianity are appropriate to Judaism. Nevertheless, the broad distinction between scientific and religious (in this case biblical, and, in my belief, biblical mythical) language is very helpful.

There is some similarity between the position I am advocating and the use of the rabbinic phrase dibrah torah bi/kilshon benei adam (the Torah speaks in human language), already found in tannaitic literature. ${ }^{57}$ The phrase was used often in medieval Jewish (Rabbanite and Karaite) literature in relation to the philosophical concept of divine accommodation, and some Modern Orthodox scholars have used it as well, even extending its purview. ${ }^{58}$ As many scholars have shown, the meaning of that phrase has not been stable and unified throughout its history; nevertheless for those who find precedents persuasive, its use throughout postbiblical interpretation may be important. It is not, however, fully identical with the position I am suggesting. To my mind, many biblical texts should be understood as metaphors, allegories, or myths, not because of divine accommodation, but rather, as I argued above, the nonliteral understanding of such texts stems from how the ancient genre of history should be understood. To repeat my earlier contention: there was little, if any, interest in the past for its own sake in antiquity, and we are mis-genrifying the Bible and reading it anachronistically if we read biblical texts as history in our modern sense.

This exploration, which has highlighted the importance of genre for understanding the issues at hand, has not answered some of the most fundamental questions that it raises: Are we to treat all narratives about the past in the Hebrew Bible in the same way? Should we make the same presuppositions about, for instance, Genesis, Exodus, Judges, Kings, Ruth, Ezra-Nehemiah, and Chronicles? More significantly, how do we know that we have interpreted a biblical text according to its correct, original genre? I simply do not believe that this question can be answered in a clear, univocal way. A glance at almost any biblical passage suggests that it has been understood in multiple ways, and been included in multiple genres. If precedent is definitive, then we are left to our own devices in understanding the genres of these texts. And I would argue further that the Jewish biblical tradition is not entirely precedent based; it is in that sense, as I stated above, that hadash is not asur min ha-Torah; the innovative is not prohibited. Thus, if modern scholarship suggests new understandings or genres that were not known by the classical and medieval rabbis, these need to be considered as well. 
Another question that I cannot answer is whether particular biblical stories should be seen only as didactic, or whether they should also be understood as using true events for didactic purposes. For example, in his gloss on the Tower of Babel story in Genesis 11:5, Rashi, basing his commentary on the Tanchuma (Noah 18 and parallels), says that biblical text states concerning "God came down to look at the city and tower" under construction: "He really did not need to do this [since He is omniscient], but Scripture intends to teach the judges that they should not proclaim a defendant guilty before they have seen the case and thoroughly understood the matter in question." Rashi's glosses here and elsewhere suggest that he read the text as primarily didacticit uses stories to teach, and is not interested in the real past for its own sake. This point is equally obvious from Rashi's initial comments on Genesis 1:1, where he does not discuss natural science, but how the text teaches that the entire world belongs to God, who may apportion it to whomever He pleases, and how the world was created for the sake of Israel or for the sake of the Torah. A fundamental question that I do not know how to answer, at least from Rashi's perspective, is whether he is saying that these stories are stories, and not literal retellings of the past, and that they are told for their didactic value (a strong claim), or if he is suggesting that these stories present real events that are told in a particular way to foster particular lessons (a much weaker claim). In either case, the story is not to be studied for its antiquarian value, for appreciating the past "wie es eigentlich gewesen."

Many will think that the most fundamental question is whether or not there are any traditions or texts that are found in the Torah that must be taken as historically true. Belief in a historical Abraham, in Moses, in the Exodus, and in the revelation at Mount Sinai come to mind as obvious candidates. I will leave it to others to decide which, if any of these, must be part of a dogmatic credo, a literal ani ma'amin (I believe). I would conclude by noting that in many of the retellings of "history" in the Bible, one or more of these "events" is omitted; consider, for example, the absence of Sinai in Deuteronomy 26:5-9 and in the historical psalms such as Psalm 136. Furthermore, the place of ani ma'aminsof dogma - in Judaism remains hotly contested. A historical survey shows that Maimonides was highly innovative here as elsewhere, and many of his ikkarim are contradicted by the classical rabbis who preceded him and the medieval and modern authorities who followed. ${ }^{59}$

Professor Menachem Kellner has made a compelling argument that Judaism insists that Jews believe in certain things, rather than believing that certain creeds are true. ${ }^{60}$ If he is correct-and I believe he is - then the fact 
that much (though not all!) of premodern Jewish interpretation took the Bible as science and as history is not terribly important. We should be free to understand the Bible using modern tools, and to decide based on our understanding of the Bible and the ancient Near East if the text indeed was meant as a straightforward historical document, conveying the "real" past. And based on both internal and external evidence, I believe that the answer is no. Though others may disagree with him and me, I hope they will consider Kellner's observation: "Two individuals can both be good Jews, fastidiously obeying the commandments, while disagreeing over fundamental matters of theology." 61

I raised the question above whether certain Jewish attitudes reflect an adoption of Christian attitudes that may not be totally at home in Judaism. For that reason, I would like to conclude this essay on Jewish attitudes to the Bible as history with a quote from Mark Noll, an Evangelical Christian, and prominent professor of American Christianity: "The Christian stake in history is immense. Every aspect of lived Christianity-worship, sacraments, daily godliness, private devotion, religiously inspired benevolence, preaching-every major theme of Christian theology - the nature of God in relation of the world, the meaning of Christ, the character of salvation, the fate of the universe-directly or indirectly involves questions about how the present relates to the past."62

How might or should one translate this quotation into Judaism? Is the Jewish stake in history "immense"? Does the entirety of Judaism concern "how the present relates to the past"? Is the Bible's literal historical veracity a crucial issue within Judaism? As my previous remarks suggest, I think that Judaism and Christianity have parted on many of these issues, and as Jews, including observant Jews, we would do well to genrify the Bible properly, and not to read it as literal history. Reading biblical texts nonliterally has ample precedents within tradition, and, to my mind, properly contextualizes the Bible within its ancient world. More importantly for me, it allows the entire Bible to become Torah, instruction, rather than an arcane recounting of past events.

\section{Endnotes}

1. I discuss the issues that are dealt with below, and many others concerning Jewish belief and the Bible, in my contributions to Marc Zvi Brettler, Peter Enns, and Daniel Harrington, The Bible and the Believer: How to Read the Bible Critically and Religiously (New York: Oxford University Press, 2012). My insistence on the importance of genre continues to be informed by John Barton, Reading the Old Testament: Method in Biblical Study, rev. ed. (Louisville, KY: Westminster John Knox, 1996.), esp. 16-18.

2. I expand on this point in my How to Read the Bible (Philadelphia: Jewish Publication Society, 2005). 
3. "Chicago Statement on Biblical Hermeneutics, with Commentary by Norman L. Geisler," Bible Research, accessed November 8, 2016, http://www.bible-researcher.com/chicago2. html.

4. On the debate over the truth, see Lee I. Levin and Amihai Mazar, eds., Ha-Pulmus al ha-Emet ha-Historit ba-Mikra [The debate over historical truth in the Bible] (Jerusalem: Yad Ben ZviDinur Center, 2002).

5. See, e.g., the recent comment by Jonathan Grossman, "Al ha-Pashtut ha-Mithadshim be-Kol Dor ve-al Ahavat ha-Torah" [On the simplicity renewed in every generation and on the love for the Torah], in Hi Sihati: Al Derekh Limmud ha-Tanakh ["It is my study"], ed. Yehoshua Rice (Alon Shevut-Jerusalem: Yeshivat Har Etzion and Sifrei Maggid, 2013), 215:

The renewal of Bible study is also connected with the faith in Providence and reality's advance towards its revelation. It is illogical that God's word, which shone for the People of Israel, was exhaustively interpreted in a particular year, and that no room remains for new interpretations. Literary studies continue to develop and become more sophisticated, and we are more and more exposed to literary tools that can reveal the message of a story to its readers. God's Torah is eternal, and even if two measures of it were revealed in earlier generations, a new measure is revealed in every generation. We have an obligation, as dwarves standing on the shoulders of giants, to add our generation's discoveries for the sake of a complete understanding of God's word. If there is awareness today of the general structure of a certain kind of story, of the development of the plot, of literary analogies, etc., we must make use of it in order to understand the Bible-in order to understand the will of God. This is devotion in God's name, a willingness to consider the smallest details, the chiastic structures, the allusions, the key words, and the parallel passages, solely in order to understand the Torah better. The truth must be stated, and this is the sweetest devotion: the greatness of the Torah unfolds again and again for the student, and the encounter with God's word and with His manners of expression enlightens the soul and brings joy.

6. Marc Zvi Brettler, The Creation of History in Ancient Israel (London: Routledge, 1995).

7. See my review of Baruch Halpern, The First Historians, in Journal of Religion 70 (1990), 83-84.

8. This definition is attributed to Leopold von Ranke (1795-1886).

9. Trans. Paula Wissing (Chicago: University of Chicago Press, 1988).

10. See, e.g., the provocative title of the article by David Pipes, "Herodotus: Father of History, Father of Lies," Loyola University New Orleans: The Student Historical Journal 30 (1998).

11. Jean-Jacques Glassner, Mesopotamian Chronicles (Atlanta, GA: Society of Biblical Literature, 2004), 26.

12. Glassner, Mesopotamian Chronicles, 39.

13. John Van Seters, In Search of History: Historiography in the Ancient World and the Origins of Biblical History (New Haven: Yale University Press, 1983), 88.

14. Mario Liverani, "The Deeds of Ancient Mesopotamian Kings," in Civilizations of the Ancient Near East, ed. Jack M. Sasson (New York: Scribners, 1995), 4:2354. 
15. Hayim Tadmor, "Propaganda, Literature, Historiography: Cracking the Code of the Assyrian Royal Inscriptions," in Assyria 1995, ed. S. Parpola and R. M. Whiting (Helsinki: The Neo-Assyrian Text Corpus Project, 1997), 333.

16. A. K. Grayson, Assyrian and Babylonian Chronicles (Locust Valley, NY: Augustin, 1975), $43-45 ; 145-151$.

17. John Van Seters, "The Historiography of the Ancient Near East," in Civilizations of the Ancient Near East, 4:2433-2444.

18. Isaiah Gafni, "rabbinic Historiography and Representations of the Past," in The Cambridge Companion to the Talmud and rabbinic Literature, ed. Charlotte Elisheva Fonrobert and Martin S. Jaffee (Cambridge: Cambridge University Press, 2007), 295.

19. Gafni, "rabbinic Historiography," 298-300.

20. See my discussion of Burkert's Structure and History in Greek Mythology and Ritual (Berkeley: University of California Press, 1982) in The Creation of History in Ancient Israel, 173.

21. Brettler, The Creation of History, $22 \mathrm{n} 44$.

22. This is the definition of the term "history" that I discussed in my The Creation of History, 12.

23. Cited in Robert Brody, Saadya Gaon, trans. Betsy Rosenberg (Oxford: Littman Library of Jewish Civilization, 2013), 67; See also Saadya Ga’on, Pirushei Rav Saadya Ga'on le-Bereshit [Saadya's commentary on Genesis], trans. and ed. Moshe Zucker (New York: Jewish Theological Seminary of America, 1984), 191-192.

24. See Joshua L. Golding, "On the Limits of Non-Literal Interpretation of Scripture from an Orthodox Perspective," Torah U-Madda Journal 10 (2001): 3-59.

25. Book 1, "Introduction to the First Part," $6 \mathrm{~b}$.

26. Mordechai Z. Cohen, Three Approaches to Biblical Metaphor: From Abraham ibn Ezra and Maimonides to David Kimhi (Leiden: Brill, 2003), 4.

27. Frank Talmage, "Apples of Gold: The Inner Meaning of Sacred Texts in Medieval Judaism," in Jewish Spirituality: From the Bible through the Middle Ages, ed. Arthur Green (New York: Crossroad, 1987), 313-355. I would like to thank Professor Alan Cooper for referring me to this important essay.

28. Talmage, "Apples of Gold," 313.

29. Ibid., 314. For more on Jewish-Christian debates concerning allegorical interpretation of Scripture, see Günter Stemberger, "Elements of Biblical Interpretation in Medieval JewishChristian Disputation,” in Hebrew Bible/Old Testament, ed. Magne Saebo (Gottingen: Vandehoeck \& Ruprecht, 2000), 578-590.

30. Talmage, "Apples of Gold," 324-325.

31. Ibid., 325.

32. Ibid., 330 .

33. A student of Nachmanides and author of a Bible commentary.

34. Ibid., 343.

35. Ibid., 344.

36. See the detailed discussion of rabbinic views in Hananel Mack, Ela Mashal Haya: Iyov va-Sefer Iyov ba-Sifrut ha-Mikrait [Job and the book of Job in rabbinic literature] (Ramat Gan: Bar Ilan University Press, 2004).

37. Moshe Greenberg, "Did Job Really Exist? An Issue of Medieval Exegesis," In Shaarei Talmon: Studies in the Bible, Qumran, and the ancient Near East Presented to Shemaryahu Talmon, ed. Michael Fishbane, Emanuel Tov, and Weston W. Fields (Winona Lake, IN: Eisenbrauns, 1992), 6-9.

38. The Guide of the Perplexed 3:22. 
39. See Avi Hurvitz, "The Date of the Prose-Story of Job Linguistically Reconsidered," Harvard Theological Review 67 (1974): 17-34.

40. See the studies by Michael Shai Cherry, in particular "Three Twentieth-Century Jewish Responses to Evolutionary Theory," Aleph 3 (2003): 247-290.

41. Abraham Yitzhak Hacohen Kook, Igrot ha-Ra'aya (Jerusalem: Mosad Harav Kook, 1962), $1: 105$.

42. Cited in Shai Cherry, "Three Responses," 286.

43. Cited in Lawrence Kaplan, "Tora U'Mada in the Thought of Rabbi Samson Raphael Hirsch," Bekhol Derakhekha Daehu: Journal of Torah and Scholarship 5 (1997): 10.

44. Kaplan, “Tora U’Mada," 11, 22-25.

45. Noah J. Efron, Judaism and Science; A Historical Introduction (Westport, CT: Greenwood, 2007), 79-98. On evolution in particular, see Geoffrey Cantor and Marc Swetlitz, eds., Jewish Tradition and the Challenge of Darwinism (Chicago: University of Chicago Press, 1996).

46. David B. Ruderman, Jewish Thought and Scientific Discovery in Early Modern Europe (Detroit: Wayne State University Press, 2001), 68-76.

47. Efron, "Judaism and Science," 116; Ruderman, "Jewish Thought," 68-76.

48. Shnayer Z. Leiman, rabbinic Responses to Modernity (Kew Garden Hills, NY: S. Z. Leiman, 2007).

49. See, for e.g., the Lubavitcher Rebbe's 1962 letter: "I can tell you without fear of contradiction that it [the theory of evolution] has not a shred of evidence to support it." Quoted in Avraham M. Hasofer, "A Statistician Looks at Neo-Darwinism," in Science in the Light of Torah: A B'or ha'Torah Reader, Herman Branover and Ilana Coven Attia, eds. (Northvale, NJ: Jason Aronson, 1994), 185. This position is expressed in some of the essays collected in Aryeh Carmell and Cyril Domb, eds., Challenge: Torah Views on Science and Its Problems (Jerusalem: Feldheim, 1976).

50. Natan Slif kin, The Challenge of Creation: Judaism's Encounter with Science, Cosmology, and Evolution (Bet Shemesh: Zoo Torah/Gefen Books, 2012); Cantor and Swetlitz, Jewish Tradition and the Challenge of Darwinism, 16-17.

51. Norbert M. Samuelson, Jewish Faith and Modern Science: On the Death and Rebirth of Jewish Philosophy (Lanham: Rowman \& Littlefield, 2009), 224.

52. Samuelson, Jewish Faith, 97.

53. Stephen Jay Gould, Rock of Ages: Science and Religion in the Fullness of Life (New York: Ballentine, 1999), 5.

54. Alvin Plantinga, Where the Conflict Really Lies: Science, Religion, and Naturalism (Oxford University Press, 2011).

55. Plantinga, Where the Conflict, ix. On this issue in non-Jewish circles, see, e.g., Harold W. Attridge, ed., The Religion and Science Debate: Why Does it Continue? (New Haven: Yale University Press, 2009); Thomas Dixon et al., eds., Science and Religion: New Historical Perspectives (Cambridge: Cambridge University Press, 2010); Ian G. Barbour, When Science Meets Religion: Enemies, Strangers, or Partners? (New York: HarperOne, 2000); Thomas Dixon, Science and Religion: A Very Short Introduction (Oxford: Oxford University Press, 2008); James W. Haag et al, eds., The Routledge Companion to Religion and Science (London: Routledge, 2012); John Hedley Brooke, Science and Religion: Some Historical Perspectives (Cambridge: Cambridge University Press, 1991).

56. Carl Feit, "Modern Orthodoxy and Evolution: The Models of Rabbi J. B. Solovetchik and Rabbi A. I Kook," in Cantor and Swetlitz, Jewish Tradition and the Challenge of Darwinism, 212 . 
57. For a history of this term, see, e.g., Haggai Ben Shammai, "Dibbrah Torah ke-Lashon Benei Adam’: Ad Kamah Lashon Benei Adam? Iyun Mashveh ba-Gishoteihem shel Rasag va-Karaim Benei Zemano" ["The Torah speaks in the language of human beings": How much "a language of human beings"? Comparative observations on the approaches of Saadya Ga'on and his contemporary critics], in Le-Yashev Peshutu shel Mikra [To settle the plain meaning of the verse: Studies in biblical exegesis] Sara Japhet and Eran Viezel, eds. (Jerusalem: Mosad Bialik, 2011), 59-69.

58. See, e.g., Joel B. Wolowelsky, "A Note on the Flood Story in the Language of Man," Tradition: A Journal of Orthodox Jewish Thought 42, no. 3 (Fall 2009): 41-48.

59. See Brettler, Enns, and Harrington, The Bible and the Believer, 32-34.

60. Menachem Kellner, Must a Jew Believe in Anything? (London: Littman Library, 2006), 9.

61. Kellner, Must a Jew Believe, 43.

62. Mark A. Noll, "History," in Dictionary for the Theological Interpretation of the Bible, ed. Kevin J. Vanhoozer (Grand Rapids, MI: Baker Academic, 2005), 295. 